\title{
Measurement errors in forest inventories and comparison of biomass estimation methods
}

\section{Erros de medição em inventários florestais e comparação de métodos para estimar biomassa}

\author{
Adriano Castelo1,*, Marcelino Guedes², Eleneide Sotta ${ }^{2}$ and Lilian Blanc ${ }^{3,4}$ \\ ${ }^{1}$ Instituto Estadual de Florestas do Amapá, Macapá, Brasil \\ ${ }^{2}$ Empresa Brasileira de Pesquisa Agropecuária (Embrapa Amapá), Macapá, Brasil \\ ${ }_{3}^{3}$ CIRAD, Forêts et Sociétés, F-34398 Montpellier \\ 4 Forêts et Sociétés, Univ Montpellier, CIRAD, Montpellier, France \\ ( ${ }^{\star} E$-mail: adrianocasteloeng@gmail.com) \\ http://dx.doi.org/10.19084/RCA18073
}

Received/recebido: 2018.03.16

Received in revised form/recebido em versão revista: 2018.05.17

Accepted/aceite: 2018.05.31

\begin{abstract}
A B S T R A C T
Accurate quantification of above-ground biomass (AGB) in managed forests requires: consideration of inventory errors and the use of local or large-scale allometric models. In this study we focus on the measurement errors, data collection errors and we compared different methods to estimate AGB in managed tropical forest. The data were collected in 15 plots of $100 \times 100 \mathrm{~m}$. We evaluated the errors of the forest inventory of 8.898 trees. We used four methods to estimate AGB: three methods which use a pan-tropical equation, which depends on wood density data, with different ways of integrating the wood density data (obtained from dataset of the Brazilian Forest Service, Jari and Global Wood Density Database - GWDD); and one local equation. The main inventory errors were: problems with the same tree being identified as a different tree in consecutive measurements ( $16 \%$ of the trees). AGB estimates using each of the four methods were significantly different.
\end{abstract}

Keywords: rainforest management, forest inventory of companies, local and pan-tropical allometric models.

\section{R E S U M O}

A quantificação precisa da biomassa acima do solo (BAS) em florestas manejadas requer: consideração de erros de inventário e o uso de modelos alométricos locais ou de larga escala. Neste estudo, nos concentramos nos erros de medição, erros de coleta de dados e comparamos diferentes métodos para estimar a BAS em florestas tropicais manejadas. Os dados foram coletados em 15 parcelas de 100 × 100 m. Avaliou-se os erros do inventário florestal de 8.898 árvores. Foram utilizados quatro métodos para estimar a BAS: três métodos que utilizam uma equação pan-tropical, que depende de dados de densidade de madeira, com diferentes formas de integrar os dados de densidade da madeira (obtidos do banco de dados do Serviço Florestal Brasileiro, Jari e Global Wood Density Database). - GWDD); e uma equação local. Entre os principais erros de inventário, destacamos problemas com a mesma árvore sendo identificada como uma árvore diferente em medições consecutivas (16\% das árvores). As estimativas de BAS utilizando cada um dos quatro métodos foram significativamente diferentes.

Palavras-chave: florestas tropicais manejadas, inventário florestal de empresas, modelos alométricos locais e pantropicais.

\section{INTRODUCTION}

Forest biomass and carbon stocks, as well as other ecosystem services can be impacted both positively and negatively by forest management. The short-term impacts vary according to the intensity of methods of logging and harvesting (West et al., 2014; Vidal et al., 2016). However, managed tropical forests represent an alternative between deforestation and full protection of the forest with the aim 
of maintenance of high biodiversity levels, carbon stocks and other environmental values even after exploitation (Putz et al., 2012).

Sustainable forest management aims to produce economic resources, social and ecological benefits continuously, respecting the support mechanisms of ecosystems (Gama et al., 2005; SFB, 2013). To ensure timber production and conservation of essential ecosystem services, such as the maintenance of carbon stocks from biomass, forest management needs to be effective on a regional scale (Imai et al., 2009; Rutishauser et al., 2015).

Moreover, estimating biomass from corporate forest inventories remains a challenge. However, uncertainties increase when working on large scales, demanding the development of new general allometric models and local validation of existing ones (Alvarez et al., 2012; Lima et al., 2012). The first challenge is related with the choice of the allometric equation and the availability of the data needed to fit in. The best-known general model to estimate biomass on a large scale is the one from Chave et al. (2005). These authors have consolidated a database of 2410 trees sampled in several tropical forests in the world, much from the Amazon, and generated equations with applicability in various regions within the pan-tropical zone. This forest biomass database comprised trees from 5 to $156 \mathrm{~cm}$ in diameter.

Dry above-ground biomass estimates using these pan-tropical equations have performed well in the Eastern Amazon (Lima, 2015). Indeed, Lima (2015) recommended the Chave et al. (2005) equation be used to estimate biomass in the Amazon region, due to its good fit and high concentration of trees sampled in this region. However, one potential barrier to the use of the Chave et al. (2005) equation is that it depends upon wood density data. Measurement of wood density requires obtaining samples which are not always possible, and the information available in the literature is poor for most species (Henry et al., 2010). The databases available on wood density in the Amazon are scarce and they do not cover the full range of tree species. Furthermore, the use of literature data creates the need for estimating the values of wood density of trees without identification.
The second challenge to improve biomass estimates in managed tropical forests are the possible problems associated with long-term monitoring, for example inventory data inconsistencies arising from forest management plans (FMP), data tabulation errors, differences in nomenclature and identification of species, and especially measurement errors of trees in the field, a frequent problem in management plans of large companies (Nogueira et al., 2005; Procópio and Secco, 2008; Lacerda and Nimmo, 2010).

The objectives of this study were to evaluate the errors and inconsistencies in the forest inventories and compare the different results of AGB ( $\left.\mathrm{Mg} \mathrm{ha}^{-1}\right)$ estimated by four different methods using a local equation (which does not require wood density data) and a pan-tropical equation (which requires wood density data), and alternatives of determining wood density for unidentified trees species.

\section{MATERIALS AND METHODS}

\section{Study area}

The study was conducted on the forest management area (FMA) of the Jari Florestal Company, located in the municipality of Almerim, state of Pará, Brazil, between latitudes $0^{\circ} 27^{\prime}$ and $1^{\circ} 30^{\prime} \mathrm{S}$, and longitudes $51^{\circ} 40^{\prime}$ and $53^{\circ} 20^{\prime} \mathrm{W}$ (Souza et al., 2014). The predominant vegetation in the study area is Sub Montane Dense Rain Forest (IBGE, 2012) and the predominant soils are yellow latosols and red-yellow ultisols.

\section{Forest inventory data from permanent plots}

We used the data from permanent plots of the Jari Florestal Company S.A. forest management area. These data were collected by an inventory team, before and after reduced impact logging (RIL), which began in 2003. The plots are 1 ha in size $(100 \mathrm{~m} \times 100 \mathrm{~m})$ and are divided into 100 subplots of $10 \mathrm{~m} \times 10 \mathrm{~m}$. In each sub-plot, trees with diameter at breast height $(\mathrm{DBH}) 1.30 \mathrm{~m}$ above the ground greater than or equal to $10 \mathrm{~cm}$ are measured.

Inconsistencies were evaluated in 8898 trees of the forest inventory. During preliminary data 
analysis, trees with repeated measurements of $\mathrm{DBH}$ in the same occasion were excluded from the database, leaving only one observation referring to that individual.

\section{Data analysis}

The commercial volume $\left(\mathrm{V}, \mathrm{m}^{3}\right)$ was calculated based on the diameter at breast height $(\mathrm{DBH}, \mathrm{cm})$ using the equation developed for dense forests in Amazonia by Nogueira et al. (2008):

$\ln ($ volume $)=\alpha+\beta \times \ln (D B H)$ (Equation 1 ; Nogueira et al., 2008)

Where: $\alpha$ and $\beta$ are -9.008 and 2.579 (R adjusted, $R^{2} a j=0.96$; Residual standard error, $R S E=0.24$ ) for trees $<40 \mathrm{~cm} \mathrm{DBH}$ and -6.860 and 1.994 for larger trees ( $\mathrm{R}$ adjusted, $\mathrm{R}^{2} \mathrm{aj}=0.80$; Residual standard error, $\mathrm{RSE}=0.22$ ).

The AGB calculation was performed only for live trees $\geq 10 \mathrm{~cm}$ of $\mathrm{DBH}$, with inventory data before reduced impact logging. Trees with $\mathrm{DBH}$ data (but not full botanical identification) were considered as Not Identified (NI) but had their $\mathrm{DBH}$ values considered for the total biomass calculation of the plot. To estimate the AGB of each sampled tree and of the forest as a whole, we used one of Chave et al. (2005) allometric equations, and one of Lima (2015) local equations.

The estimate of aboveground biomass (AGB, $\mathrm{Mg} \mathrm{ha}^{-1}$ ) using the pan-tropical equation (Equation 2) is based on diameter at breast height $(\mathrm{DBH}, \mathrm{cm})$ and wood density $\left(\mathrm{p}, \mathrm{g} \mathrm{cm}^{-3}\right)$, as follows:

$A G B=p \times e^{\left(-1.499+2.148 \times \ln (D B H)+0,207 \times(\ln (D B H))^{2}-0.0281 \times(\ln (D B H))^{3}\right)}$

(Equation 2; Chave et al., 2005), Multiple R-squared, $\mathrm{R}^{2}=0.99$; Residual standard error, $\mathrm{RSE}=0.35$ )

Wood density values were obtained from the databases of Jari Florestal SA, Global Wood Density Database (GWDD) - Chave et al. (2009), Zanne et al. (2009) and the Brazilian database, compiled by the Forest Products Laboratory of the Brazilian Forest Service. We organized and consolidated a list of genus occurring in the area and found in all three consulted databanks (Table 2). When we found more than one value per genus, the average wood density was used for according to the methodology used by Rutishauser et al. (2010) and Medjibe et al. (2011).

The estimate of dry aboveground biomass (DAGB, $\mathrm{Mg} \mathrm{ha} \mathrm{a}^{-1}$ ) using the local equation was calculated from a simple entry model, with diameter at breast height $(\mathrm{DBH}, \mathrm{cm})$ as the independent variable (Equation 3):

$\ln D A G B=-1.97256+2.44723 \times \ln D B H$ (Equation 3; Lima (2015); R adjusted, $\mathrm{R}^{2} \mathrm{aj}=0.96$; Residual standard error, $\mathrm{RSE}=0.437$; F-statistic, $\mathrm{F}=4958.94$ ).

To compare the estimates of total biomass of the plots four methods were used to estimate biomass. They were defined depending on the calculation method and the form used to estimate the wood density of the species for which data were not available:

METHOD 1: Chave et al. (2005) equation, with Global wood density data (GWDD). For identified species without wood density and for the NI, we used the genus average and the overall average $(\mathrm{p}=$ 0.62) of the available timber densities, respectively.

METHOD 2: Chave et al. (2005) equation with average wood density of the three databases (GWDD, SFB and JARI). For individuals without wood density and for the NI, we used the Lima (2015) equation, which does not require wood density data.

METHOD 3: Lima (2015) equation for all individuals in the inventory.

METHOD 4: Chave et al. (2005) equation with average wood density of the three databases (GWDD, SFB and JARI), considering the large trees $(\mathrm{DBH}>156 \mathrm{~cm})$ as $\mathrm{DBH}=156$.

The diameter of 19 trees were higher than the diametric interval scope $(\mathrm{DBH}>156 \mathrm{~cm})$ for the Chave et al. (2005) and Lima (2015) equations.

The biomass values for the trees above the diametric scope $(\mathrm{DBH}>156 \mathrm{~cm})$ of the equations were estimated by extrapolation (in Methods 1, Method 2 and Method 3) according to the methodology used by West et al. (2014). 
For our study we assumed a maximum diameter growth of $2 \mathrm{~cm} \mathrm{yr}^{-1}$, based on the literature such as those reported by Braz et al. (2015) of $1.26 \mathrm{~cm}$ year-1, and by Dauber et al. (2005) of $1.3 \mathrm{~cm} \mathrm{yr}^{-1}$ for similar forest types in the Brazilian Amazon. When there were at least two measurements with consistent values for the same tree, the inconsistent values of negative growth and excessive positive growth were corrected by the average of the consistent growths. Only those individuals whose values were inconsistent in all measurements were eliminated from the database for the evaluation of the dynamics, maintaining the first measurement for biomass calculations.

The mean biomass value estimated using the four methods was calculated for the 15 plots. The four methods were compared by $F$ test $(n=15)$ at the $5 \%$ error probability level and the confidence interval for the averages between the four methods was calculated. The statistical analyses were performed using the $R$ programming language $(R$ Development Core Team, 2015).

\section{RESULTS AND DISCUSSION}

\section{Errors and inconsistencies in inventories}

We identified four types of inconsistencies (Table 1) more recurrent in forest inventory data: 1) error in the nomenclature of species (NI); 2) measurement of negative $\mathrm{DBH}$; 3) $\mathrm{DBH}$ growth measurement above $2 \mathrm{~cm}$ per year; and 4) lack of information on wood density.

The most frequently occurring inconsistency was related to the nomenclature of species, especially with the exchange of the common name of the

Table 1 - Major inconsistencies in data from permanent plots of forest management monitoring inventories in the eastern Amazon $(n=8898)$

\begin{tabular}{lccccc}
\hline Source of error & (NI) & G(-) & G>2cm & NospN/D $^{\mathbf{s}}$ & NotreeN/D \\
\hline Quantity & 1426 & 694 & 514 & 7 & 44 \\
$(\%)$ & 16.03 & 7.80 & 5.77 & 0.08 & 0.49 \\
\hline
\end{tabular}

Nomenclature errors (NI), negative DBH growth (G -), positive growth of over 2 $\mathrm{cm}_{\text {year }}{ }^{-1}(\mathrm{G}>2 \mathrm{~cm})$, number of species without wood density data (NOsp N/D) and number of trees without wood density data (NotreeN/D). same tree between measurements. This is due to difficulties in maintaining permanent and experienced teams in the field for carrying out the inventories and during the entry of field data to computers. Moreover, the lack of qualified professionals in the botanical identification service and the lack of collection of materials for identification can contribute to this type of error during corporate inventories.

The most common identification errors are: a) assigning different names for the same species; $b$ ) variation in the common names in different places; c) changes in species identification identified in previous measurements (Nogueira et al., 2005, Procópio and Secco, 2008; Lacerda and Nimmo, 2010). According to reports from the field teams, these errors occur due to fatigue caused by the great physical effort required to stay in the field for long and continued periods in the Jari Florestal's area. Lacerda and Nimmo (2010) emphasize that in the Brazilian Amazon, the most common method used to identify tree species in the field is using local people and local ecological knowledge.

Errors related to negative growth values can be explained by changes of the point of measurement. This is a common problem in corporate inventories where marking of the measurement spot on the trees is not a common practice. The same problem can occur for very high positive values, when a growth rate in diameter higher than expected for tropical forests is observed, because measurements are made below the level of the previous year.

\section{Wood density for Eastern Amazon}

In our database, 44 trees of seven species remained without a value for wood density and the wood density variation within the genus was high for some species (Supplementary Data), as in the case of the genus Aniba, which showed a variation of 0.37 to $1.05 \mathrm{~g} \mathrm{~cm}^{-3}$.

The use of the genus average to estimate the density of the wood species that do not have information, as performed by Chave et al. (2005) and Medjibe et al. (2011) can be a source of error in the estimates of the biomass of trees. This type of error can be particularly observed in genera such as the 
Swartzia, which have many species and a high variation, i.e. the variation of this genus in our study was 0.54 to $0.92 \mathrm{~g} \mathrm{~cm}^{-3}$.

The most commonly used equations for estimating biomass stored in tropical forests depend on wood density, but this information is frequently not easy to obtain in the field. Most studies use information from the literature or a structured database. However, the databases are not always accessible to all potential users. The present study makes available information on wood density at the genus level for tropical forest species that occur in the eastern Amazon, systematized from three databanks (Supplementary Data).

\section{Biomass estimates}

The maximum diameter between plots ranged from 85.9 to $288.7 \mathrm{~cm}$ (Table 2), the number of large trees with a diameter $\geq 60 \mathrm{~cm}$ also varied considerably, from 3 to 27 trees.

The commercial volume per plot ranged from 196 to $554.2 \mathrm{~m}^{3} \mathrm{ha}^{-1}$. Plots with a concentration of large trees and the majority of which had maximum
DBHs, had larger volumes when compared to other assessments carried out in the same forest typology, 328.33 to $408.69 \mathrm{~m}^{3} \mathrm{~h}^{-1}$ (Souza et al., 2006). The lower volume found in P-11 shows the importance of large trees for volume and biomass estimates in the forest, with few trees over $60 \mathrm{~cm}$ in diameter and no tree greater than $156 \mathrm{~cm}$, indicating that most of the trees in the plot are thin, as identified in the studies of Mazzei et al. (2010), Medjibe et al. (2011), Sist et al. (2014) and West et al. (2014).

The estimated AGB calculated by Method 1 ranged from 234.5 to $936.59 \mathrm{Mg}^{\mathrm{a}}{ }^{-1}$ among plots, with Method 2 from 217.02 to $881.11 \mathrm{Mg}^{-1} \mathrm{a}^{-1}$, with Method 3 from 157.94 to $619.95 \mathrm{Mg} \mathrm{ha}^{-1}$ and with Method 4 from 217.01 to $716.69 \mathrm{Mg} \mathrm{ha}^{-1}$ (Table 3).

The average AGB estimated by Method 1 and Method 3 showed significant differences $(F=2.76$, $\mathrm{DF}=13, \mathrm{p}=0.05$ ) based on their confidence intervals, showing that AGB estimates can be influenced according to the choice of approach (Figure 1). The equation which uses wood density as a predictive variable estimated higher AGB compared to that estimated by the local equation without wood density. The Methods 1, 2 and 4, based on DBH

Table 2 - Data on density of trees, maximum DBH, average DBH, number of large trees, species richness (Rsp) and volume (Vol) from the 15 plots of Jari Florestal Company

\begin{tabular}{|c|c|c|c|c|c|c|c|}
\hline \multirow[b]{2}{*}{ Plot } & D & DBHmax & DBHm & № & № & \multirow[b]{2}{*}{ R sp. } & \multirow{2}{*}{$\begin{array}{c}\text { Vol } \\
\left(\mathrm{m}^{3} \mathrm{ha}^{-1}\right)\end{array}$} \\
\hline & (n.ha-1) & $(\mathrm{cm})$ & $(\mathrm{cm})$ & $(\geq 60 \mathrm{~cm})$ & $(\geq 156 \mathrm{~cm})$ & & \\
\hline P-12 & 527 & 288.7 & 23.7 & 22 & 3 & 124 & 554.2 \\
\hline P-10 & 479 & 286.5 & 24.4 & 25 & 2 & 89 & 507 \\
\hline P-01 & 436 & 254.7 & 24.5 & 23 & 3 & 123 & 466.3 \\
\hline P-08 & 430 & 251.5 & 21.9 & 7 & 5 & 104 & 396.2 \\
\hline P-14 & 465 & 231.4 & 23.5 & 15 & 3 & 126 & 412.4 \\
\hline P-05 & 567 & 189.5 & 24.3 & 21 & 2 & 127 & 521.4 \\
\hline P-06 & 435 & 173.8 & 24.9 & 19 & 1 & 110 & 397.5 \\
\hline P-15 & 562 & 134.9 & 22.5 & 20 & - & 136 & 385.4 \\
\hline P-02 & 513 & 127.3 & 22.2 & 12 & - & 160 & 313.5 \\
\hline P-13 & 593 & 122.6 & 20.1 & 5 & - & 109 & 264.7 \\
\hline P-03 & 527 & 121.9 & 23.3 & 27 & - & 118 & 396.8 \\
\hline P-07 & 464 & 114.6 & 23.7 & 19 & - & 105 & 337.8 \\
\hline P-04 & 509 & 106.7 & 23.3 & 15 & - & 87 & 336.3 \\
\hline P-11 & 414 & 102.2 & 19.7 & 9 & - & 106 & 196 \\
\hline P-09 & 581 & 85.9 & 19.9 & 3 & - & 104 & 247.5 \\
\hline (15ha) & 7502 & - & - & 242 & 19 & - & 5733 \\
\hline Average & 500 & 172.8 & 22.8 & 16 & 3 & 115 & 382.2 \\
\hline
\end{tabular}

Data on density of trees (D), maximum DBH (DBHmax), average DBH (DBHm), number of large trees (No), species richness (Rsp) and commercial volume (Vol). 
Table 3 - Above-ground biomass ( $\mathrm{AGB}, \mathrm{Mg} \mathrm{ha}^{-1}$ ) and commercial volume (Vol, $\mathrm{m}^{3} \mathrm{ha}^{-1}$ ) per plot, total and average (IC 95\%), calculated by four different Methods

\begin{tabular}{|c|c|c|c|c|c|}
\hline Plot & AGB1* & AGB2* & AGB3* & AGB4* & Vol \\
\hline P-01 & 736.74 & 701.33 & 496.82 & 573.45 & 466.3 \\
\hline P-02 & 363.36 & 348.80 & 259.74 & 383.95 & 313.5 \\
\hline P-03 & 508.53 & 487.78 & 343.15 & 487.80 & 396.8 \\
\hline P-04 & 390.69 & 369.68 & 269.60 & 369.68 & 336.3 \\
\hline P-05 & 749.77 & 728.86 & 492.42 & 700.97 & 521.4 \\
\hline P-06 & 544.10 & 528.84 & 360.21 & 517.42 & 397.5 \\
\hline P-07 & 403.96 & 389.57 & 274.06 & 389.57 & 337.8 \\
\hline P-08 & 681.31 & 618.26 & 466.74 & 435.23 & 396.2 \\
\hline P-09 & 277.69 & 273.21 & 189.05 & 273.23 & 247.5 \\
\hline P-10 & 749.41 & 708.62 & 548.21 & 520.80 & 507 \\
\hline P-11 & 234.50 & 216.97 & 157.94 & 217.02 & 196 \\
\hline P-12 & 936.59 & 885.68 & 619.95 & 716.69 & 554.2 \\
\hline P-13 & 290.85 & 297.93 & 209.25 & 297.94 & 264.7 \\
\hline P-14 & 613.43 & 577.86 & 417.86 & 487.72 & 412.4 \\
\hline P-15 & 483.20 & 467.79 & 332.48 & 467.79 & 385.4 \\
\hline Total & 7964.13 & 7601.20 & 5437.49 & 6839.26 & 5733 \\
\hline Average IC (95\%) & $530.94 \pm 115.46$ & $505.87 \pm 107.25$ & $362.49 \pm 77.39$ & $455.95 \pm 79$ & $382.2 \pm 57$ \\
\hline
\end{tabular}

*Above-ground biomass (AGB) estimated by Method 1 (AGB1), AGB estimated by Method 2 (AGB2), AGB estimated by Method 3 (AGB3) and AGB estimated by Method 4 (AGB4).

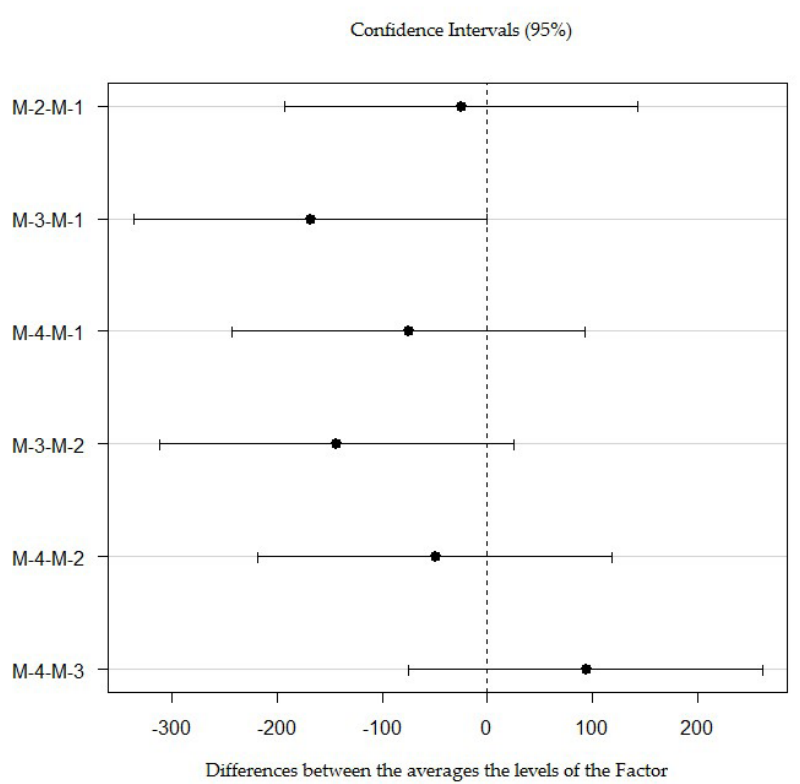

Figure 1 - Confidence intervals of the means for the four Methods (Method 1 (M-1), Method 2 (M-2), Method $3(M-3)$ and Method $4(M-4))$ proposed to calculate AGB of the 15 permanent plots of Jari Florestal Company. and wood density, showed greater variation in estimates due to the need to also estimate some wood density data. The Method 3 which does not depend on this variable had the lowest variation.

Some authors (i.e. Medjibe et al., 2011; Sist et al., 2014) prefer to replace DBHs of larger individuals by the maximum scope DBH. In our study, we did this substitution in Method 4, which resulted in $14 \%$ reduction in the estimated average biomass. These data show the importance of these large trees for biomass estimates in sites with many trees of this size, such as the Jari Florestal area.

Biomass estimates using Method 1, Method 2 and Method 4 (based on the global equation and the wood density) were quite high in relation to some estimates of biomass in the Amazon. In Central Amazon, Lima et al. (2012) estimated $253 \mathrm{Mg} \mathrm{ha}^{-1}$. In Eastern Amazon, Mazzei et al. (2010) found an average of $409.8 \mathrm{Mg} \mathrm{ha}^{-1}$, in the same region Sist et al. (2014) found $378 \mathrm{Mg} \mathrm{ha}^{-1}$, West et al. (2014) estimated $260 \mathrm{Mg} \mathrm{ha}^{-1}$ and Vidal et al. (2016) estimated around $237 \mathrm{Mg} \mathrm{ha}^{-1}$. 
The calculation of the AGB using Method 3 proved to be more conservative relative to the other methods because it is a local model based on a single input variable (i.e. DBH). Another indication that this method may be more reliable is that it was the only one to estimate the biomass below the commercial volume. Biomass estimates greater than the volumes (i.e. Method 1, Method 2 and Method 4) imply a predominance of wood densities greater than $1 \mathrm{Mg} \mathrm{m}^{-3}$, and this would not be consistent with the density values of most species (Supplementary Data).

\section{CONCLUSIONS}

The nomenclature inconsistencies and species identification were preponderant for AGB determination, analyzes indicated that the errors and inconsistencies of forest business inventories may compromise the quality of AGB estimates. The possible solutions to the studied problem are the promotion of knowledge about the diversity of forest species in the region and the increase of efforts in the modelling works in the Amazon biome.

We suggest the use of local allometric models (a model based on DBH only and without wood density data) in situations where the information for wood density is scarce, especially when there is not the correct identification of some forest species.

\section{REFERENCES}

Alvarez, E.; Duque, A.; Saldarriaga, J.; Cabrera, K.; Salas, G.; Valle, I.; Lema, A.; Moreno, F.; Orrego, S. \& Rodriguez, L. (2012) - Tree above-ground biomass allometries for carbon stocks estimation in the natural forests of Colombia. Forest Ecology and Management, vol. 267, p. 297-308. https://doi.org/10.1016/j.foreco.2011.12.013

Braz, E.M.; Mattos, P.P.; Thaines, F.; Madron, L.D.; Garrastazu, M.C.; Canetti, A. \& d'Oliveira, M.V.N. (2015) - Criteria to be considered to achieve a sustainable second cycle in Amazon Forest. Pesquisa Florestal Brasileira, vol. 35, n. 83, p. 209-225. https://doi.org/10.4336/2015.pfb.35.83.941

Chave, J.; Andalo, C.; Brown, S.; Cairns, M.A.; Chambers, J.Q.; Eamus, D.; Fölster, H.; Fromard, F.; Higuchi, N.; Kira, T.; Lescure, J.-P.; Nelson, B.W.; Ogawa, H.; Puig, H.; Riéra, B. \& Yamakura, T. (2005) - Tree allometry and improved estimation of carbon stocks and balance in tropical forests. Oecologia, vol. 145, n. 1, p. 87-99. https://doi.org/10.1007/s00442-005-0100-x

Chave, J.; Coomes, D.A.; Jansen, S.; Lewis; S.L.; Swenson, N.G. \& Zanne, A.E. (2009) - Towards a worldwide wood economics spectrum. Ecology Letters, vol. 12, n. 4, p. 351-366. https://doi.org/10.1111/j.1461-0248.2009.01285.x

Dauber, E.; Fredericksen, T.S. \& Peña, M. (2005) - Sustainability of timber harvesting in Bolivian tropical forests. Forest Ecology and Management, vol. 214, n. 1-3, p. 294-304. https://doi.org/10.1016/j.foreco.2005.04.019

Gama, J.R.V.; Bentes-Gama, M.M. \& Scolforo, J.R.S. (2005) - Manejo sustentado para floresta de várzea na Amazônia oriental. Revista Árvore, vol. 29, n. 5, p. 719-729. http://dx.doi.org/10.1590/S0100-67622005000500007

Henry, M.; Besnard, A.; Asante, W.A.; Eshun, J.; Adu-Bredu, S.; Valentini, R.; Bernoux, M. \& Saint-André, L. (2010) - Wood density, phytomass variations within and among trees, and allometric equations in a tropical rainforest of Africa. Forest Ecology and Management, vol. 260, n. 8, p. 1375-1388. https://doi.org/10.1016/j. foreco.2010.07.040

IBGE (2012) - Instituto Brasileiro de Geografia e Estatística. Manual técnico da vegetação brasileira (Manuais Técnicos em Geociências). 2ª Edição. Rio de Janeiro, Brasil. https://biblioteca.ibge.gov.br/visualizacao/livros/liv63011.pdf.

Imai, N.; Samejima, H.; Langner, A.; Ong, R.C.; Kita, S.; Titin, J.; Chung, A.Y.C.; Lagan, P.; Lee, Y.F. \& Kitayama, K. (2009) - Co-benefits of sustainable forest management in biodiversity conservation and carbon sequestration. PLoS One, vol. 4, n. 12, art. e8267. https://doi.org/10.1371/journal.pone.0008267

Lacerda, A.E.B. \& Nimmo, E.R. (2010) - Can we really manage tropical forests without knowing the species within? Getting back to the basics of forest management through taxonomy. Forest Ecology and Management, vol. 259, n. 5, p. 995-1002. https://doi.org/10.1016/j.foreco.2009.12.005 
Lima, A.J.N.; Suwa, R.; Mello Ribeiro, G.H.P.; Kajimoto, T.; Santos, J.; Pereira da Silva, R.; Sampaio de Souza, C.A.; Castro de Barros, P.; Noguchi, H.; Ishizuka, M. \& Higuchi, N. (2012) - Allometric models for estimating above - and below - ground biomass in Amazonian forests at São Gabriel da Cachoeira in the upper Rio Negro, Brazil. Forest Ecology Management, vol. 277, p. 163-172. https://doi.org/10.1016/j. foreco.2012.04.028

Lima, R.C. (2015) - Equations to estimate above-ground biomass in the north Eastern Amazon rainforests. Dissertação de Mestrado. Recife, Universidade Federal Rural de Pernambuco. 50 p.

Mazzei, L.; Sist. P.; Ruschel, A.; Putz, F.E.; Marco, P.; Pena, W. \& Ferreira, J.E.R. (2010) - Above-ground biomass dynamics after reduced-impact logging in the Eastern Amazon. Forest Ecology and Management, vol. 259, n. 3, p. 367-373. https://doi.org/10.1016/j.foreco.2009.10.031

Medjibe, V.P.; Putz, F.E.; Starkey, M.P.; Ndouna, A.A.; Memiaghe, H.R. (2011) - Impacts of selective logging on above-ground forest biomass in the Monts de Cristal in Gabon. Forest Ecology and Management, vol. 262, n. 9, p. 1799-1806. https://doi.org/10.1016/j.foreco.2011.07.014

Nogueira, E.M.; Nelson, B.W. \& Fearnside, P.M. (2005) - Wood density in dense forest in central Amazonia, Brazil. Forest Ecology and Management, vol. 208, n. 1-3, p. 261-286. https://doi.org/10.1016/j.foreco.2004.12.007

Nogueira, E.M.; Fearnside, P.M.; Nelson, B.W.; Barbosa, R.I. \& Keiser, E.W.H. (2008) - Estimates of forest biomass in the Brazilian Amazon: New allometric equations and adjustments to biomass from woodvolume inventories. Forest Ecology and Management, vol. 256, n. 11, p. 1853-1867. https://doi.org/10.1016/j. foreco.2008.07.022

Procópio, L.C. \& Secco, R.S. (2008) - A importância da identificação botânica nos inventários florestais: o exemplo do "tauari" (Couratari spp. e Cariniana spp. - Lecythidaceae) em duas áreas manejadas no estado do Pará. Acta Amazonica, vol. 38, n. 1, p. 31-44. http://dx.doi.org/10.1590/S0044-59672008000100005

Putz, F.E.; Zuidema, P.A.; Synnott, T.; Peña-Claros, M.; Pinard, M.A.; Sheil, S.; Vanclay, J.K.; Sist, P.; GourletFleury, S.; Griscom, B.; Palmer, J. \& Zagt, R. (2012) - Sustaining conservation values in selectively logged tropical forests: the attained and the attainable. Conservation Letters, vol. 5, n. 4, p. 296-303. https://doi. org/10.1111/j.1755-263X.2012.00242.x

R Development Core Team. (2015) - R: a language and environment for statistical computing. R Foundation for Statistical Computing, Vienna, Austria; 2015. https://www.r-project.org/

Rutishauser, E.; Hérault, B.; Baraloto, C.; Blanc, L.; Descroix, L.; Sotta, E.D.; Ferreira, J.; Kanashiro, M.; Mazzei, L.; d'Oliveira, M.V.N.; Oliveira, L.C.; Peña-Claros, M.; Putz, F.E.; Ruschel, A.R.; Rodney, K.; Roopsind, A.; Shenkin, A.; Silva, K.E.; Souza, C.R.; Toledo, M.; Vidal, E.; West, T.A.P.; Wortel, V. \& Sist, P. (2015) - Rapid tree carbon stock recovery in managed Amazonian forests. Current Biology, vol. 25, n. 18, p. R787-R788. https://doi.org/10.1016/j.cub.2015.07.034

Rutishauser, E.; Wagner, F.; Herault, B.; Nicolini, E.-A. \& Blanc, L. (2010) - Contrasting above-ground biomass balance in a Neotropical rain forest. Journal of Vegetation Science, vol. 21, n. 4, p. 672-682. https://doi. org/10.1111/j.1654-1103.2010.01175.x

SFB (2013) - Florestas do Brasil em resumo. Serviço Florestal Brasileiro, Ministério do Meio Ambiente, Brasília. http://www.florestal.gov.br/snif

Sist, P.; Mazzei, L.; Blanc L. \& Rutishauser, E. (2014) - Large trees as key elements of carbon storage and dynamics after selective logging in the Eastern Amazon. Forest Ecology and Management, vol. 318, p. 103109. http://dx.doi.org/10.1016/j.foreco.2014.01.005

Souza, D.R.; Souza, A.L.; Leite, H.G. \& Yared, J.A.G. (2006) - Análise estrutural em floresta ombrófila densa de terra firme não explorada, Amazônia oriental. Revista Árvore, vol. 30, n. 1, p. 75-87. http://dx.doi.org/10.1590/ S0100-67622006000100010

Souza, A.L.; Medeiros, R.M.; Matos, L.M.S.; Silva, K.R.; Corrêa, P.A. \& Faria, F.N. (2014) - Estratificação volumétrica por classes de estoque em uma floresta ombrófila densa, no município de Almeirim, Estado do Pará, Brasil. Revista Árvore, vol. 38, n. 3, p. 533-541. http://dx.doi.org/10.1590/S0100-67622014000300016

Vidal, E.; West, T.A.P. \& Putz, F.E. (2016) - Recovery of biomass and merchantable timber volumes twenty years after conventional and reduced-impact logging in Amazonian Brazil. Forest Ecology and Management, vol. 376, p. 1-8. https://doi.org/10.1016/j.foreco.2016.06.003 
West, T.A.P.; Vidal, E. \& Putz, F.E. (2014) - Forest biomass recovery after conventional and reduced-impact logging in Amazonian Brazil. Forest Ecology and Management, vol. 314, p. 59-63. https://doi.org/10.1016/j. foreco.2013.11.022

Zanne, A.E.; Lopez-Gonzalez, G.; Coomes, D.A.; Ilic, J.; Jansen, S.; Lewis, S.L.; Miller, R.B.; Swenson, N.G. Wiemann, M.C. \& Chave, J. (2009) - Data from: Towards a worldwide wood economics spectrum. Dryad Digital Repository. https://doi.org/10.5061/dryad.234 